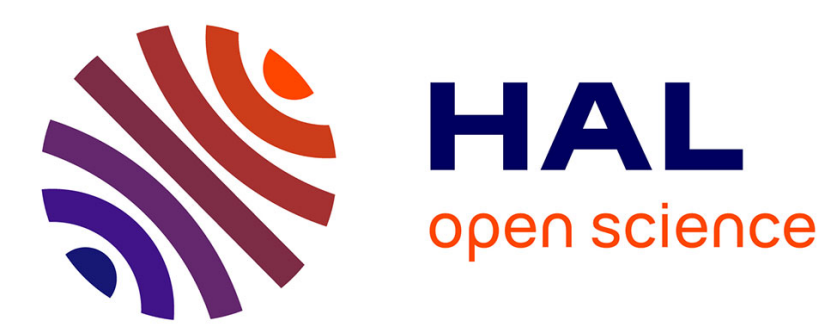

\title{
Non-destructive Sensing Projects beneath the Auxerre cathedral
}

\author{
Michel Dabas, Harry B Titus
}

\section{To cite this version:}

Michel Dabas, Harry B Titus. Non-destructive Sensing Projects beneath the Auxerre cathedral. GESTA - the International Center of Medieval Art, 2001, XL (2), pp.181-188. hal-02925477

\section{HAL Id: hal-02925477 \\ https://hal.science/hal-02925477}

Submitted on 29 Aug 2020

HAL is a multi-disciplinary open access archive for the deposit and dissemination of scientific research documents, whether they are published or not. The documents may come from teaching and research institutions in France or abroad, or from public or private research centers.
L'archive ouverte pluridisciplinaire HAL, est destinée au dépôt et à la diffusion de documents scientifiques de niveau recherche, publiés ou non, émanant des établissements d'enseignement et de recherche français ou étrangers, des laboratoires publics ou privés. 


\title{
Non-Destructive Sensing Projects beneath Auxerre Cathedral*
}

\author{
MICHEL DABAS \\ CNRS, Paris
}

HARRY B. TITUS, JR.

Wake Forest University

Abstract

Teams of researchers from the Centre National de la Recherche Scientifique led by Michel Dabas recently made electrostatic and radar surveys to locate structural elements lying beneath the paving in the nave of Auxerre Cathedral. While the radar survey made use of established technology, the electrostatic survey was conducted with prototype equipment developed by CNRS/Garchy personnel. Technically, the descriptive superiority of the electrostatic method was demonstrated, though the radar survey provided more accurate indications of the depth of sub-surface features. Computerized maps presenting the collected data in color-coded form are here interpreted by the authors and coordinated with documentary and physical evidence pertaining to the building history of Auxerre Cathedral. The primary goal of the project was to gather information about the eleventh-century cathedral that was gradually replaced in the Gothic period. The data, however, permitted the authors to develop hypotheses about pre-Romanesque structures and about the construction sequence of the extant Gothic building.

During the summer of 1998 two non-destructive sensing projects were carried out in tandem in the cathedral of SaintEtienne in Auxerre (Figs. 1, 2). The first employed an electrostatic system developed at the Centre de Recherches Géophysiques de Garchy to capture measurements of electrical resistance. The second made use of a ground-penetrating radar system (GPR). ${ }^{1}$ The goal of the two coordinated projects was to gather information concerning eleventh-century Romanesque structures, and perhaps even earlier remains, that might exist beneath the paving of the nave and transept of the present Gothic cathedral.

Both sensing methods were originally developed for other purposes, namely, to locate subterranean natural resources and to analyze the potential of agricultural sites. Fixed-position electrostatic sensing has also frequently been used at open-air archaeological sites. But established procedures are not suitable inside historic monuments, where spatial constraints preclude their use. The geophysicists and engineers at Garchy have been working to adapt existing technologies to meet the needs of archaeologists at sites with existing structures in continued use. Their results are increasingly precise, bringing to

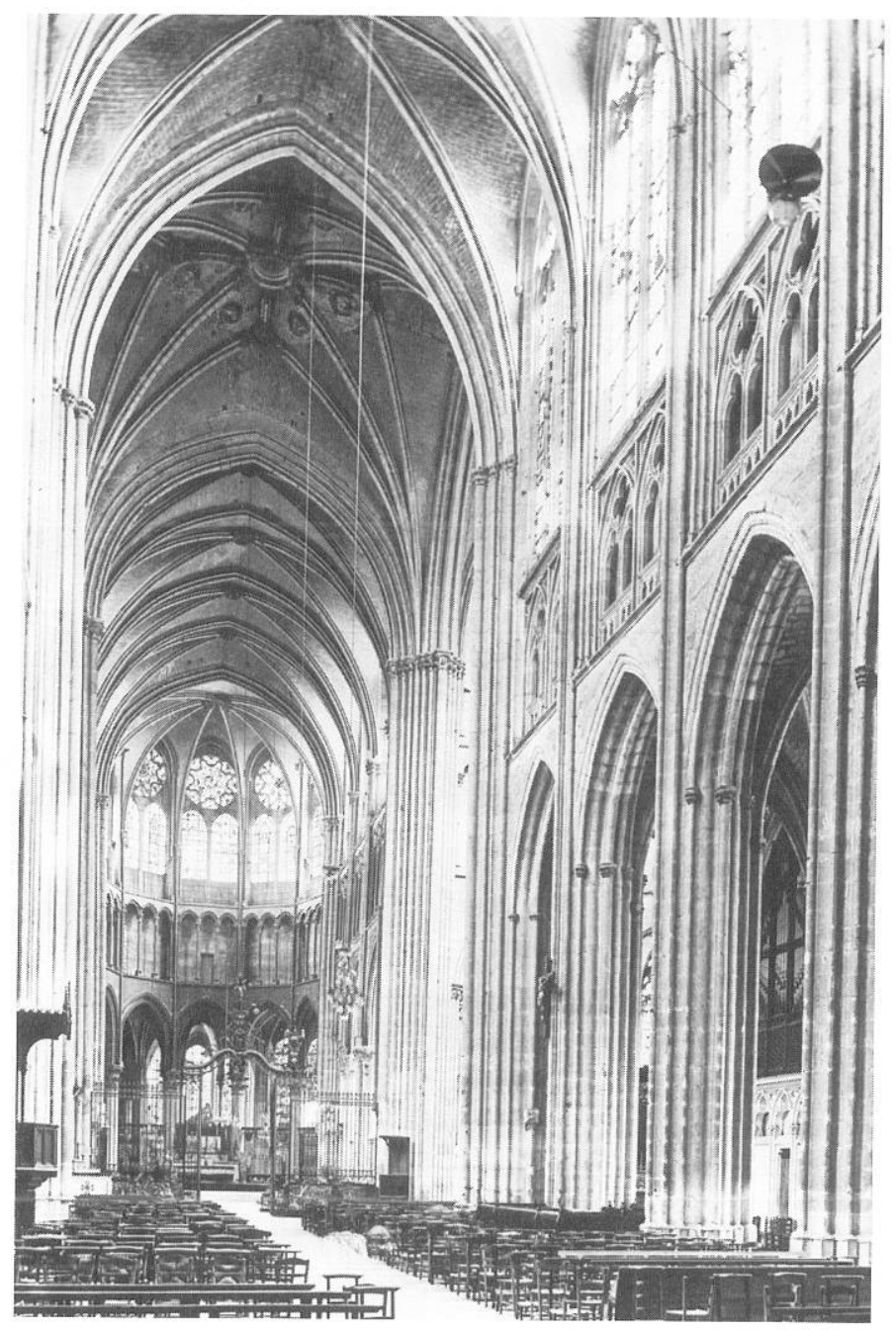

FIGURE 1. Auxerre Cathedral, interior to east (photo: Centre des monuments nationaux, Paris, Collection médiathèque du patrimoine).

light information that is useful both on its own merits and because it can serve to direct more traditional archaeological research. The Auxerre project is one of the first demonstrations of the potentials of the electrostatic prototype. 


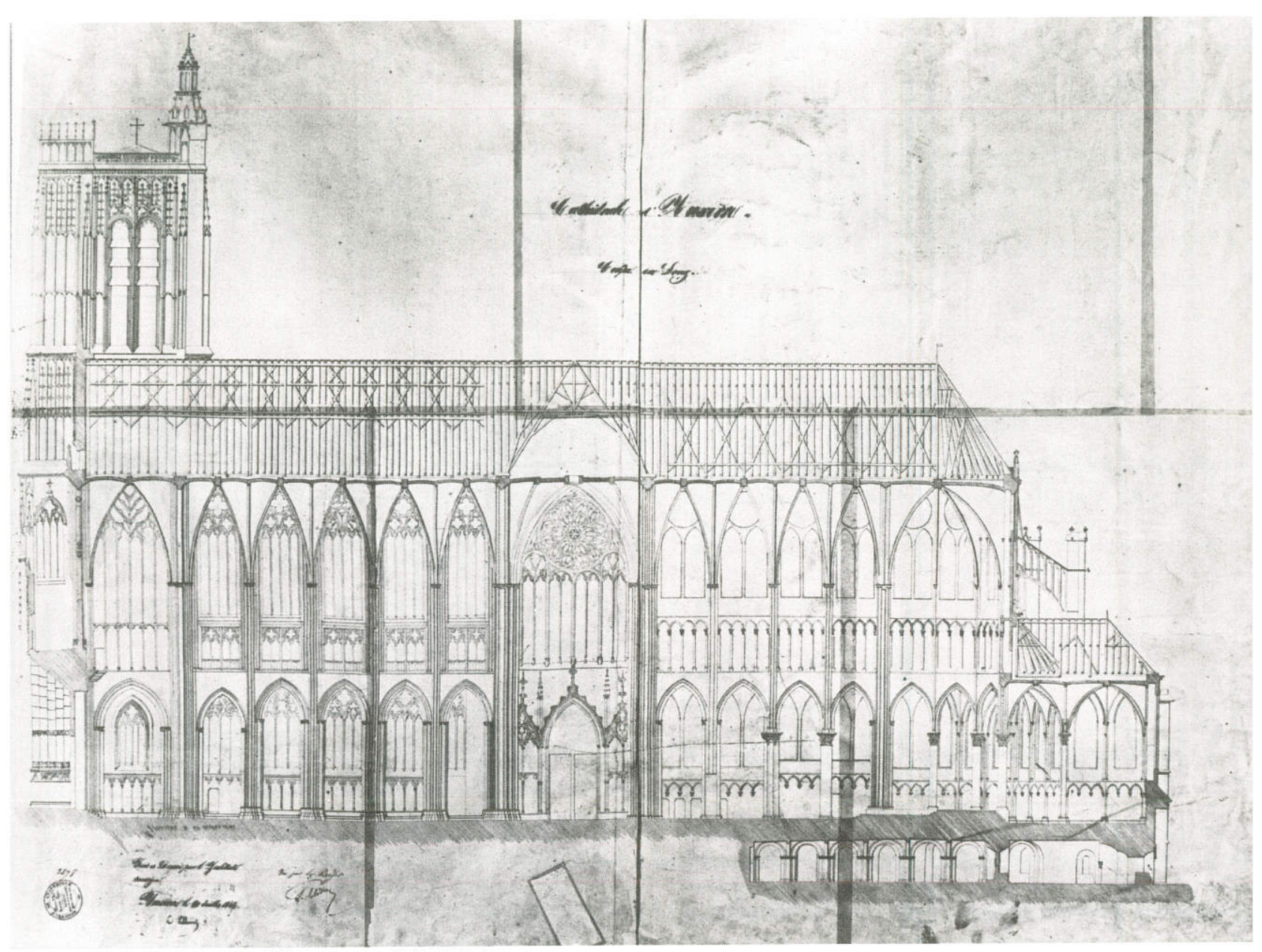

FIGURE 2. Auxerre Cathedral, longitudinal section (photo: Centre des monuments nationaux, Paris, Collection médiathèque du patrimoine).

The team made three surveys of the nave, nave aisles, and crossing: a longitudinal radar survey, a longitudinal electrostatic survey, and a transverse electrostatic survey. Twelve maps were produced from the collected data, representing soundings at various depths beneath the present paving. The radar reflections changed considerably from one depth to another; therefore they proved more useful in establishing the depth of a given anomaly. The electrostatic results provided much clearer indications of the horizontal limits of the anomalies. The two methods are complementary and permit more complete verification of the data than would be possible using either alone. We present for discussion two maps, showing a set of results from the longitudinal electrostatic and the longitudinal radar surveys (Color Plates 1, 2).

The immediate impetus for the surveys was a desire to gather information about remains beneath the cathedral's nave that might be related to the extant eleventh-century crypt. Documentary evidence pertaining to the building history of the eleventh-century cathedral is derived primarily from the compilation of the lives of the bishops of Auxerre, the so-called
Gesta pontificum Autissiodorensium. ${ }^{2}$ From this text we learn that a reconstruction of the cathedral was begun during the episcopate of Hugues de Chalon (r. 999-1039). Two fires are mentioned in the account of Hugues' life. The first is reported to have damaged all the churches in the city with the exception of St. Alban. The second is said to have occurred after Hugues had undertaken to rebuild the cathedral, including the extant crypt; the new work was apparently not affected. ${ }^{3}$ No specific dates for the fires are recorded in the Gesta pontificum, but they are dated 1023 and 1036 in a thirteenth-century manuscript documenting events in the diocese of Auxerre. ${ }^{4} \mathrm{It}$ is likely that the cathedral, as rebuilt after the 1023 fire, was complete by about 1040 , although it was not formally dedicated until 1057, after Bishop Geoffroy de Champ-Aleman had its interior redecorated and refurbished. ${ }^{5}$ The church had a single portal as its western entry until, at the end of the twelfth century, Bishop Hugues de Noyers (r. 1183-1206) commissioned two flanking doorways. ${ }^{6}$

Based on indications gleaned from the various bishops' lives in the Gesta pontificum, and on the shape and size of the 


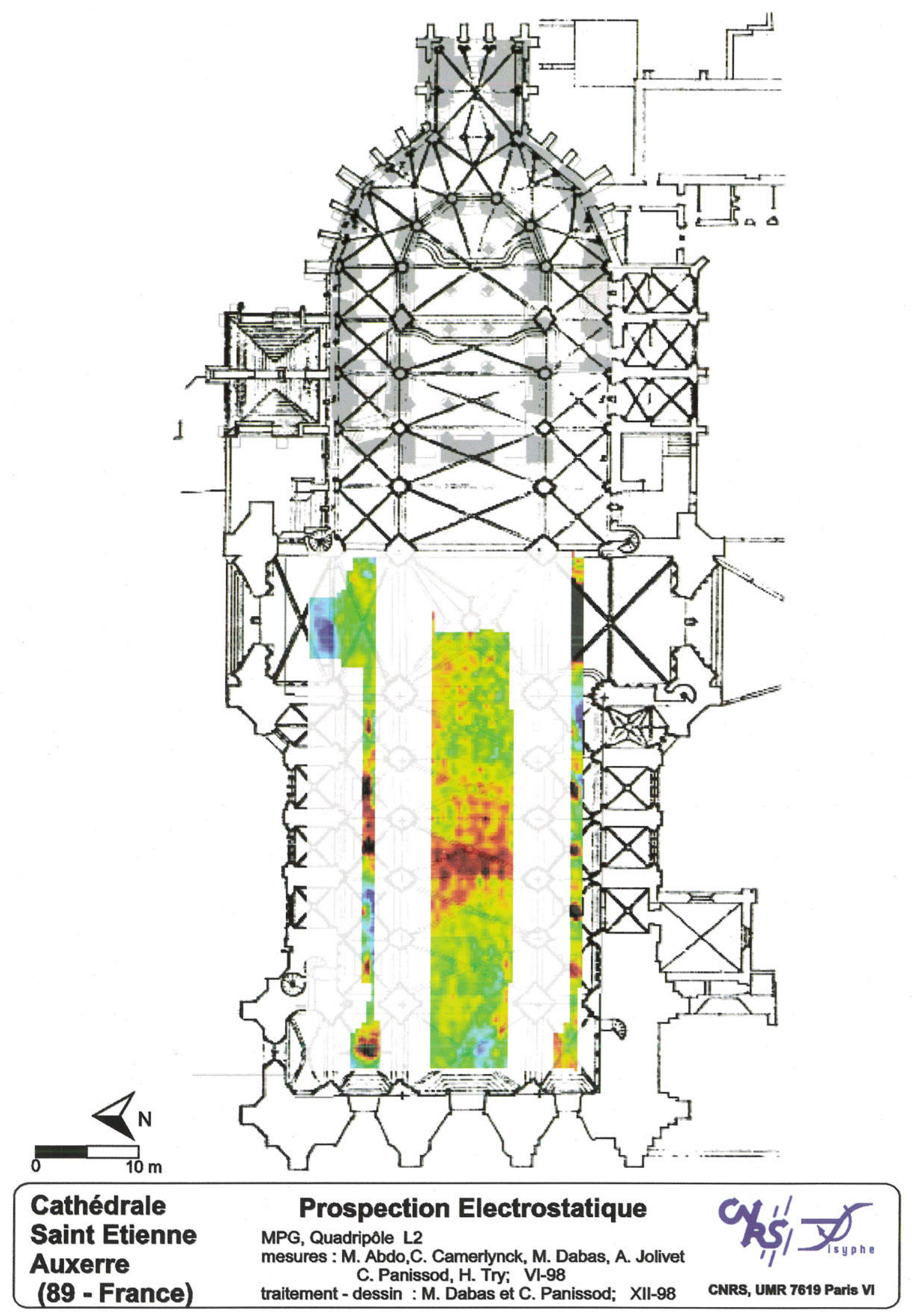

PLATE 1. Auxerre Cathedral, plan with electrostatic image (CNRS; prepared by Michel Dabas). 


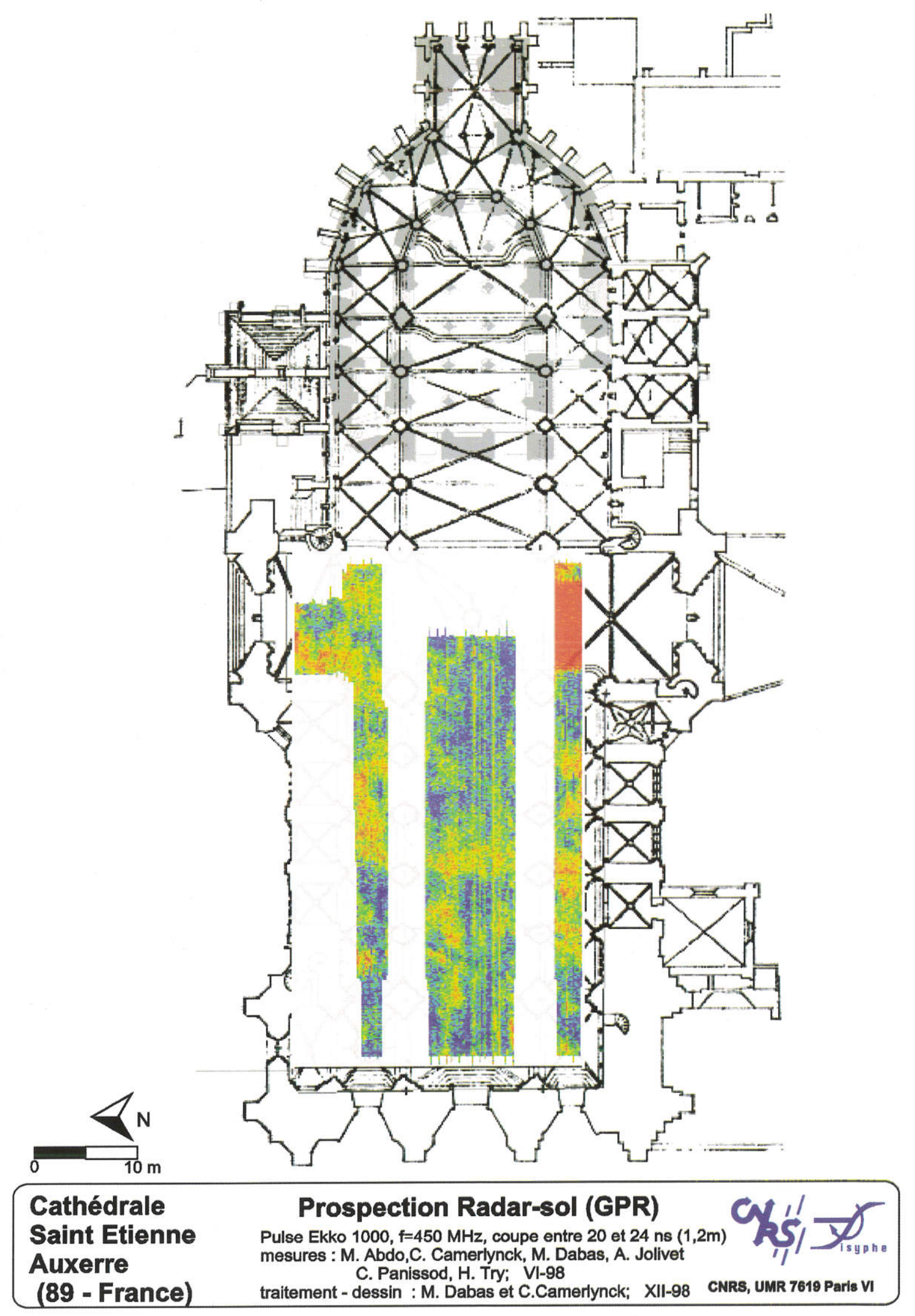

PLATE 2. Auxerre Cathedral, plan with radar image (CNRS; prepared by Michel Dabas). 
existing crypt, it seems that the eleventh-century cathedral was composed of a sanctuary with an ambulatory and an axial chapel, a nave with side aisles, and a single western portal. A transept is never mentioned in the written records. Since the documents also mention two towers flanking the entrance to the choir, ${ }^{7}$ we imagine a building resembling in profile St.Germain-des-Prés in Paris or Notre-Dame at Melun-churches that had a similar aspect in the first half of the eleventh century. ${ }^{8}$

The current surveys were designed to search for evidence of the continuation of the exterior walls along the line established by the extant crypt walls. We expected that indications of the eleventh-century foundations would appear between the piers of the Gothic nave, since the spacing of the earlier elements would have been different from the spacing of the Gothic supports. It also seemed possible that the façade of the eleventh-century building might appear as a transverse element beneath the current nave.

The surveys turned up a prominent transverse anomaly in the fourth bay of the nave counting west-east. This anomaly, we believe, is very likely associated with the western façade of the cathedral as rebuilt after the fire of 1023, whose crypt is still extant. At 3 meters thick, it is certainly substantial enough to be the lower section of an important enclosing wall. Moreover, in the north arm of the transept the surveys revealed a clear line of demarcation running east-west along the alignment of the crypt's exterior wall. This line probably marks the limit of the exterior wall of the eleventh-century cathedral. We know that a baptistery and a treasury existed to the east of the north transept arm from the twelfth century. ${ }^{9}$ Given the location of the east-west element, it does not appear that the Romanesque cathedral could have had a projecting transept. If these two indicators are correct, the overall exterior dimensions of the eleventh-century cathedral can be projected as 81 meters long and 27 meters wide.

Merging the new data with historical material, we can say with greater certainty that the eleventh-century cathedral consisted of an axial western portal, a nave with side aisles, and a sanctuary with a single axial chapel. Bishop Humbaud (r. 1087-1114) is credited with the erection of a wooden spire above the axial chapel block, ${ }^{10}$ and towers over the side aisles of the chevet were added during the twelfth century. The overall silhouette of the pre-Gothic structure is suggested in Figure 3.

Although the first and most straightforward goal of the surveys was to establish the dimensions of the eleventh-century cathedral, it also seemed possible that indications of yet earlier structures might be detected. The cathedral that was damaged in the fire of 1023 had been constructed during the episcopate of Gui (r. 933-961) to replace a ninth-century cathedral that had itself been damaged by fire. ${ }^{11}$ A noteworthy feature of Gui's rebuilding was a western tower or porch, first mentioned in the life of Bishop Abbon (r. 857-860), ${ }^{12}$ but apparently much modified over the years. In the earlier documents, it is called cocleam, which is associated with the English word "shell." The term may indicate either an element curved in plan or a three-dimensional structure, such as a vaulted area. Gui's cathedral also had two oratoria, located to the left and right of the main altar, which, with the sanctuary, formed a cross at the eastern end of the cathedral. It seemed possible that the surveys might succeed in locating elements of the western structure and/or parts of the curving oratories in the eastern part of the extant nave or crossing.

The area immediately to the east of the transverse element that we interpret as the eleventh-century façade revealed a pattern of seemingly related rectilinear anomalies. ${ }^{13}$ The pattern suggests three possibilities. First, the anomalies might indicate the existence of a tribune protruding inward from the eleventh-century façade, although there is no mention of such an arrangement in historical sources. Second, they might register remnants of the axial tower of the Carolingian cathedral, mentioned in connection with bishops Abbon and Gui in the ninth and tenth centuries respectively. Third, they might record evidence that the 1023 fire did not completely destroy the preRomanesque cathedral and that portions of its western section were retained and/or renovated when the new façade was constructed. Exploratory excavation would be necessary to confirm any of these hypotheses. ${ }^{14}$

In the area immediately to the west of the transverse anomaly in bay 4 , there appeared what seems to be a curved or splayed pattern centered on the axis of the plan. The feature is more noticeable north of the axis and shows more clearly in some maps than others. This suggests that there was some type of fore-structure in front of the main façade block of the eleventh-century cathedral. If there was a structure in this position, it could date to any point between the eleventh century and 1500, when the completion of the Gothic cathedral brought this zone within the building envelope.

Another goal of the survey project was to shed light on the sequences of construction in the extant Gothic cathedral. Documentary evidence indicates that the new chevet was begun about 1215 and completed near the middle of the thirteenth century (Fig. 4). ${ }^{15}$ During the second half of the century the existing southwest portal was erected considerably to the west of the eleventh-century façade; the northwest portal was constructed only after a gap in time, in a separate campaign (Fig. 5). It is clear from masonry breaks that the entire west complex was raised to a point slightly above the first horizontal cornice by the early fourteenth century. At this time construction of a new nave was begun, which connected the chevet with the recently completed western portals. By the end of the fourteenth century the crossing, nave aisles, five side chapels, and the three eastern bays of the central nave were in use (Fig. 6). ${ }^{16}$ The western three bays of the central nave were not vaulted until the first half of the sixteenth century, after the west façade had been extended above the portal level (Figs. 7 and 2). ${ }^{17}$ Between ca. 1240 and 1320 the cathedral thus consisted of a low portal block, the eleventh-century nave and the thirteenth-century chevet (Fig. 5). Between ca. 1350 and 1500 new nave aisles linked the portals and the 
FIGURE 3. Auxerre Cathedral, proposed profile ca. 1150.

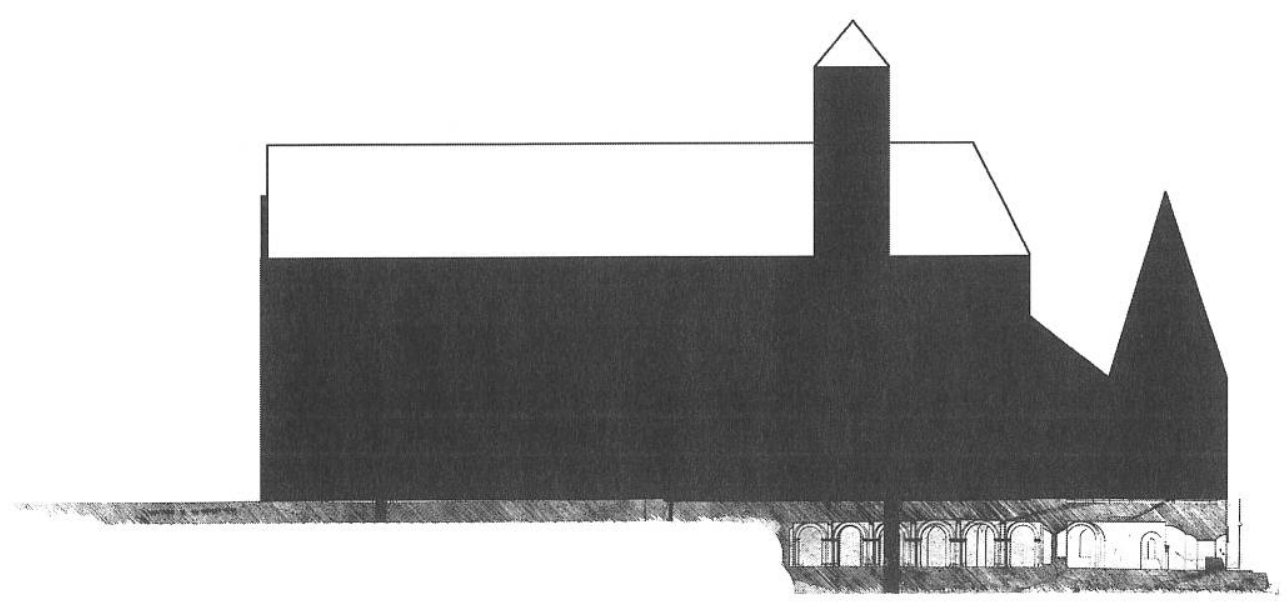

FIGURE 4. Auxerre Cathedral, proposed

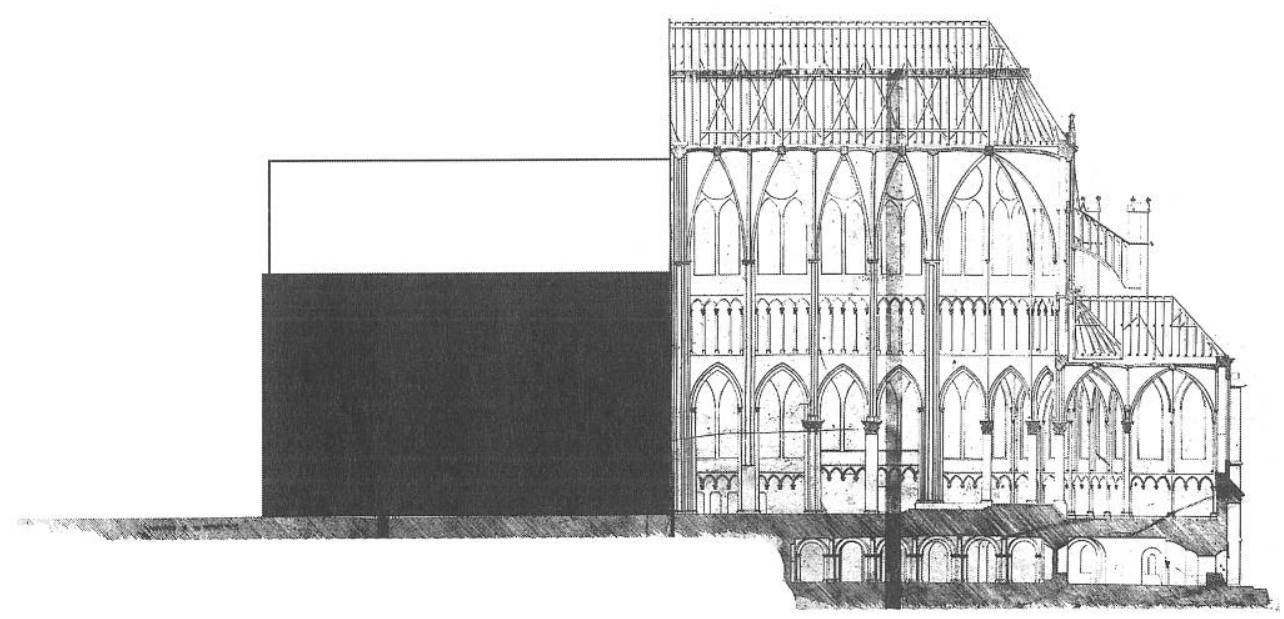

profile ca. 1240 .

chevet, but the central nave remained incomplete in the western bays (Fig. 7).

It is clear that the building programs of the thirteenth century were informed by the intention to enlarge the cathedral by extending it further to the west than its predecessors. The strategy of moving the entry block westward was dictated by the decision to retain the eleventh-century crypt as the foundation for the Gothic chevet. Because the chevet was only slightly wider than the Romanesque nave, the builders could easily link the new and old sections at the eastern crossing piers. At the west, they laid the foundation for the Gothic façade approximately 20 meters beyond the existing west façade. The first construction campaign, as mentioned above, was limited to the southern portal with its massive accompanying wall and interior pier, completed to a point just above the first cornice (Fig. 5). From this portal block it was another 12 meters eastward to the position of the earlier façade. Thus, for a con- siderable period of time there was a gap between nave and portals (Fig. 5). Radar and electrostatic sensing in bays 1 and 2 of the present cathedral indicated that the area below the central nave is relatively undisturbed. But anomalies on the south side of these bays, aligned E-W, may be associated with a temporary enclosure that linked the new south portal with the older façade.

Beginning in the 1340s, members of the cathedral chapter began to establish lateral chapels and to dedicate altars in the Gothic nave. The first documented inhumation in this part of the cathedral is that of Pierre de Dicy, who was buried in 1358 in the south arm of the transept. ${ }^{18}$ An independent goal of the survey was to recover the actual locations of some of the nave burials, which could then be checked against documentary evidence for possible identification. Although we know there were numerous burials in the nave side aisles and side chapels, repavings of the nave between the seventeenth and 


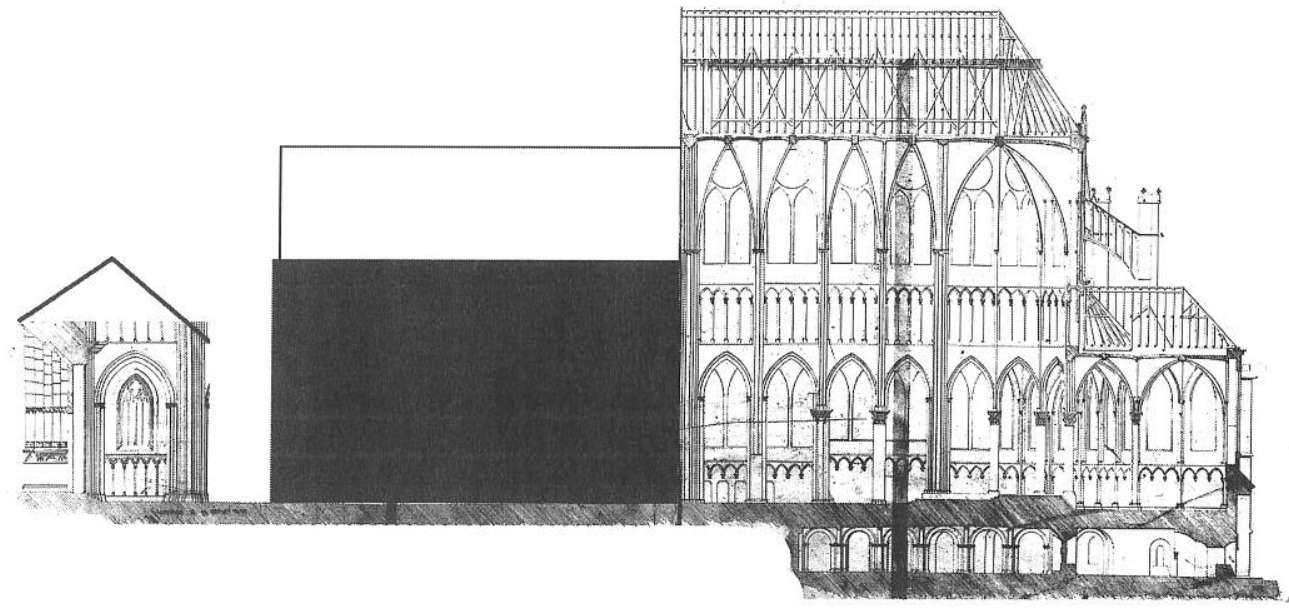

FIGURE 5. Auxerre Cathedral, proposed profile ca. 1300.

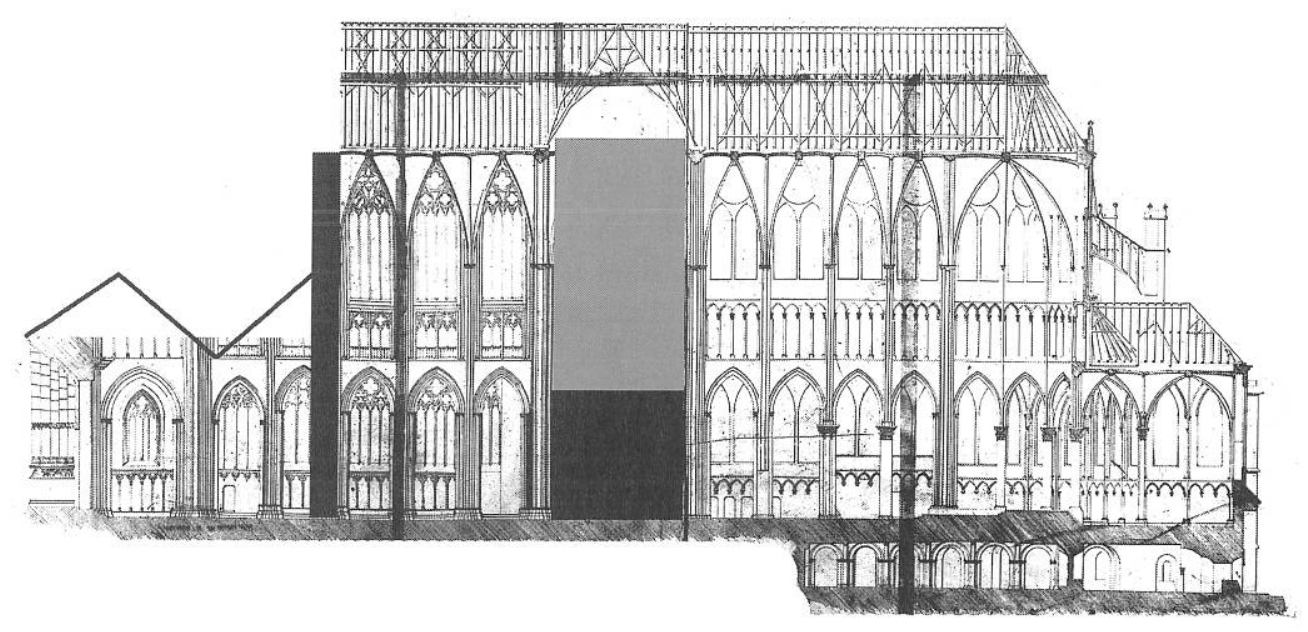

FIGURE 6. Auxerre Cathedral, proposed profile ca. 1400 .

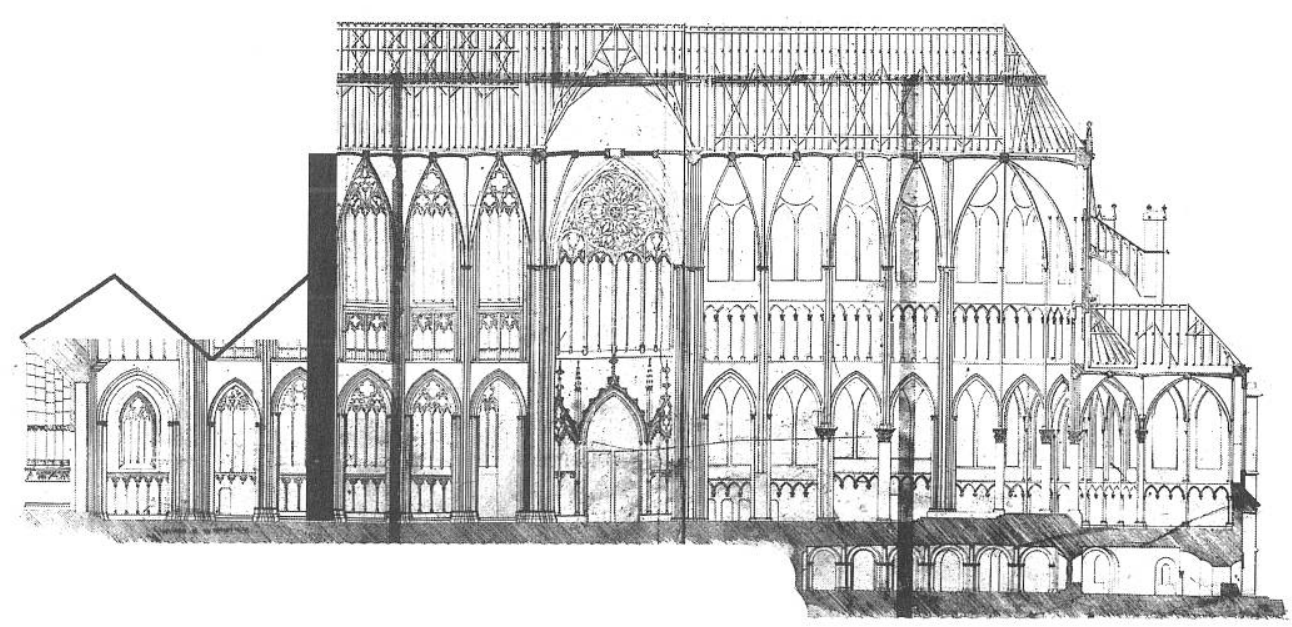

FIGURE 7. Auxerre Cathedral, proposed profile ca. 1500. 
nineteenth centuries have obscured their number and location. At present the nave aisles are paved with reused funerary slabs from many periods, most of their inscriptions now effaced. The slabs were re-installed in an arbitrary pattern, most of them set in pairs more or less centered in the eastern four nave aisle bays.

The surveys established that the central nave is free of anomalies associated with burials, but the side aisle bays each have areas of increased resistivity, reflected on the map as black zones. These zones are voids: the large black area in the south arm of the transept marks the void that is the modern heating room. In other cases the voids may be presumed to represent tomb chambers. It is documented that, beginning in the second half of the fourteenth century, chapels were added on the nave periphery: on the south, three chapels at bays 5 , 4 , and 3 , and on the north, two chapels at bays 5 and 4 . The side aisle anomalies that are the most pronounced and most similar to one another are located precisely in the bays in front of these chapels. Although there are indications of less regular, but similar, features in other aisle bays, they do not have the character of this group of five. The remainder of the nave chapels were constructed in the later fifteenth or sixteenth century. The irregular anomaly in the north aisle of bay 1 is very likely the burial site of a canon interred in 1496, who was placed "at the foot of the stairs." ${ }^{19}$ We may conclude that there was an important and distinctive program of inhumations associated with chapel building and patronage beginning in the second half of the fourteenth century. ${ }^{20}$

Up to this point we have discussed the nature of anomalies as revealed by remote sensing and their possible associations with existing or documented structures. If, however, we are correct in our assessment of the location of the eleventhcentury façade, a further, more speculative, hypothesis may be proposed. As we have argued, when the Gothic chevet was constructed between $c a$. 1215 and $c a$. 1240, the eleventh-century nave, abutting the present eastern crossing piers, was retained (Fig. 4). Construction of the new western block followed (Fig. 5), and then a new nave was erected slowly throughout the fourteenth century (Fig. 6). By ca. 1400 the eastern three nave bays had received their high vaults, but the western three bays could not be continued in their upper sections until the façade block was raised to the same height. This project was undertaken $c a$. 1500. Therefore, between 1400 and 1500 a temporary wall must have existed between the third and fourth nave bays (Fig. 7). It does not seem to be a coincidence that this is the projected location of the eleventh-century façade. Based on the new evidence, it can be suggested that this temporary wall was the Romanesque façade itself: it would have remained standing across the central nave until the final campaign of enclosure during the period $1500 / 20,{ }^{21}$ after which it would finally have been removed (Fig. 2).
Our recently-completed laser survey of the entire cathedral indicates that the north and south nave peripheral walls are not in perfect alignment, suggesting that they were erected around the Romanesque nave. In this context of incremental replacements, the obvious reworking of the Gothic piers at the east of bay 2 suggests that they were left at least partly unprotected on the "exterior" of the space temporarily enclosed in the fourteenth century. Also, sockets still exist in the main arcade spandrels of the second nave bay for transverse beams that may have served to support the temporary roof over the west block and western nave bays.

After hypothesizing that the Romanesque façade was left standing while the new Gothic building was completed around it, we began to consider a similar scenario for the delayed completion of the north transept arm. Although construction began in the south arm of the transept in the fourteenth century, only the lower west wall of the north arm was included in the new periphery. A campaign to finish the north arm was begun ca. 1410, but it stalled and was not concluded until the end of the fifteenth century. ${ }^{22}$ Another temporary enclosure must have been needed to connect the aisles of the chevet and the nave, and it would have followed the alignment of the exterior wall of the eleventh-century aisle. Again, it is possible that for economy's sake the exterior wall of the Romanesque cathedral served as the base for the temporary enclosure, which, in this case, would have been needed between $c a .1310$ and ca. 1480 (Fig. 6). Establishing likely physical limits for the Romanesque cathedral therefore permits us to propose a more dynamic construction history for the Gothic cathedral and to trace the sequence in which its new sections gradually replaced Romanesque work.

In summary, the survey has provided results of three types. First, it has shown the efficacy of the electrostatic prototype, which, in this case, yielded more evocative information than the radar technique. Second, it has furnished important indications about the size and shape of the pre-Gothic buildings at Auxerre: it is very probable that the data indicate the exterior dimensions of the Romanesque cathedral and locate its façade. Third, it has yielded information relating to the building history of the Gothic cathedral and its use. The locations of inhumations in the side aisles were clearly indicated, and it seems equally clear that there was not a significant program of burial in the nave proper. Relationships between the Romanesque and Gothic building programs are more speculative, but provide bases for further study. These results clearly demonstrate the usefulness of non-destructive sensing techniques. They may be used to guide further study through excavation but, even if that step is not taken, they can support new hypotheses about the history of a site. 
Appendix: Electrostatic and Radar Sensing Procedures

The collected data was synthesized into eight sets: two longitudinal profiles and two transverse profiles at two different depths. In order to correlate the new information with the ground plan of the cathedral, the following procedure was adopted: a plan of the Gothic cathedral provided by the Service des Monuments Historiques (28 juillet 1911) was scanned into a computer, and a plan of the Romanesque crypt produced by Olivier Juffard and Harry Titus (1994) was superposed as a transparency. Finally a third plan of the nave piers, hand-measured by Harry Titus, was digitized and superposed on the Gothic plan, pier centers being indicated by crosses. The apparent range of error was about $0.5 \mathrm{~m}$. Tomb slabs reemployed as side-aisle paving were located as reference points and correlated with the three other plans. Finally, the geophysical surveys were imported as color transparencies and positioned on the plans. The range of error in all the plans is on the order of $1 \mathrm{~m}$.

\section{A. Electrostatic System}

The electrostatic sensing system was developed and refined by Alain Jolivet at the Centre de Recherches Géophysiques de Garchy (prototype MPG). The system permits the measurement of electrical resistance in an area underlying an electrically isolated surface. The classic methods that assume an injection of current by metal electrodes are obviously not operable on such surfaces. In the case of a paved floor in a cathedral, current is injected by electrostatic effect, and the electrical potential generated by this current is also measured. It is by noting the relationship between the measured potential and the injected current that the resistivity of the terrain is obtained. Resistivity is a function of the structures through which the current passes. In the case of a void or of masonry elements resistivity will be higher (orange-red and black on the printouts). In the case of conductive structures, which are generally more humid, or of earthen areas, resistivity will be lower (green and blue on the printouts). The depth to which the current can penetrate is a function not only of the encountered material but also of the geometry of the poles employed (the relative position of the poles in relation to one another). In the case of the prototype MPG, two geometries permit the investigation of two levels, approximately 1 and 2 meters deep respectively.

In order to cover a maximum of surface area in the area under study, the apparatus was pulled longitudinally along the nave and side aisles (E-W), and also transversally (N-S). The positioning of the measurements is effected by establishing reference points at each end of straight-line traverses. Measurements are recorded by a computer every $5 \mathrm{~cm}$. The traverses are spaced $20 \mathrm{~cm}$ apart. The average length of the longitudinal traverses was $42 \mathrm{~m}$, and of the transverse, $23 \mathrm{~m}$. This study is the first to use such a tight grid of measurements; it is clear that the high quality of the resulting images is tied both to the grid and to the electronic capabilities of the prototype.
The measurements were compiled and visualized in real time in the form of profiles in a portable computer. Later, in a second operation, the profiles were associated to form a map of apparent underground resistivities (reorganized on a grid of $0.2 \times 0.2 \mathrm{~m})$. There are as many maps as there are geometries.

\section{B. Radar System}

A commercial system-Sensors and Software, Pulse Ekko 1000 - was employed, using a frequency of $450 \mathrm{MHz}$, compatible with the maximum depth of the structure being studied. In principle the method involves the emission of an electromagnetic wave into the soil by means of an emitting antenna and the measurement of echoes from various underground elements by means of a receiving antenna. In order for there to be an echo, there must be variations in the electromagnetic properties of the materials traversed (conductivity and/or dielectric constant).

Only longitudinal profiles were made in the nave and side aisles. The size of the apparatus is considerably smaller than the electrostatic equipment, so it was possible to take measurements closer to the walls and piers. Therefore, transverse mapping was not necessary. Profiles were taken at $20 \mathrm{~cm}$ intervals. A wheel odometer measured the distance traveled and emitted a signal every $5 \mathrm{~cm}$. In real time, the amplitude of the echoes can be determined as a function of time (therefore of depth) and of distance traveled. The time of the echo indicates the depth of the target material, information not provided by the electrostatic method.

In order to represent this information, the amplitude of the signal is selected for a time interval $d t$, corresponding to a depth interval of $d z$ centered at depth $z$. The energy is then computed for this interval and for every radar trace corresponding to the points collected along the surface. These points are interpolated to create a map (time-slice) that represents the energy scattered and reflected at depth $z$. By increasing the time period, deeper and deeper structures can be described. Given an average propagation speed of $10 \mathrm{~cm} / \mathrm{ns}$, with the first interval centered on $6 \mathrm{~ns}$, an average depth of $30 \mathrm{~cm}$ is measured (the time is doubled to account for the emission / reflection / reception). The deepest interval is centered on $34 \mathrm{~ns}$, or $1.7 \mathrm{~m}$. Beyond that horizon the radar wave is not energetic enough to penetrate and return to the surface. Eight levels were measured and positioned on the cathedral plan.

The manipulation of radar data is not yet exact enough to compensate for certain defects. In particular, profile lines that are systematically different from surrounding lines must be discounted (poor connections between the antenna and the surface and/or poor coordination of time). The analysis of radar images remains very complex and time consuming in comparison to the assessment of images derived from electrostatic procedures. 


\section{NOTES}

* The electrostatic procedure was carried out by Michel Dabas, Alain Jolivet, Mounir Abdo, and Huynh Try. Michel Dabas, Christian Camerlynck, and Cédric Panissod were responsible for the radar survey.

1. See Appendices A and B for technical information concerning the two procedures.

2. The Gesta pontificum, preserved as MS 142 in the Bibliothèque municipale, Auxerre, is published by L. M. Duru in Bibliothèque historique de l'Yonne (Auxerre, 1850), I, 309-509.

3. Gesta pontificum, ed. Duru, 389-392.

4. The dates are marginal notes in Paris, Bibliothèque nationale de France, MS lat. 5253, published by A. Vidier and L. Mirot in Obituaires de la Province de Sens, III. Orléans, Auxerre, Nevers (Paris, 1909), xxxvii.

5. Gesta pontificum, ed. Duru, 396.

6. Ibid., 448.

7. The towers are first mentioned in the life of Bishop Robert de Nevers (r. 1076-1084) (ibid., 400). See below, n. 15.

8. Both buildings have towers that flank the chevet east of the transept. At Auxerre, where there does not seem to have been a transept, it is more likely that the towers were located over the side aisles and were not as firmly supported as they are in the existing buildings. See J. Hubert, "Les dates de construction du clocher-porche et de la nef de Saint-Germaindes-Prés," BMon, CVIII (1950), 69-84; Y. Gallet, "Les tours de chevet de Notre-Dame de Melun: Nouvelles hypothèses chronologiques," BMon, CLVI-3 (1998), 237-256.

9. The treasury is extant; the baptistery immediately to its west was constructed during the reign of Bishop Guillaume de Toucy (r. 11671181) (Gesta pontificum, ed. Duru, 427). It was still indicated in a 1713 city plan now in the Archives de l'Yonne but was demolished during the Revolutionary period.

10. Gesta pontificum, ed. Duru, 403-404. The spire collapsed in a windstorm that occurred during the episcopate of Hugues de Montaigu (r. 11151136) (ibid., 415-416).

11. Ibid., 379-381.

12. Ibid., 356.
13. Yet farther to the east there is a checkered pattern of anomalies, whose regularity is more pronounced on some maps than those illustrated here. We have no firm suggestions based on historical sources for the meaning of these anomalies.

14. Exploratory excavations in the nave and crypt based on the survey results are scheduled for June 2002.

15. Ibid., 474-485. The life of Guillaume de Seignelay (r. 1207-1220) recounts that the Romanesque towers flanking the choir collapsed during reconstruction in 1217. The date of completion for the chevet is less clear, but the fact that Bishop Henri de Villeneuve (r. 1220-1234) was interred in the cathedral has led scholars to believe that the chevet was completed by 1234 (ibid., 486).

16. The transept and nave program was begun under Bishop Pierre de Grez (r. 1309-1325). This is indicated by an indulgence granted to benefactors of the fabric by Pope Jean XXII in 1321. See G. Mollat, Jean XXII (1316-1334): Lettres communes analysées d'après les registres dits d'Avignon et du Vatican, III (Paris, 1906), 275. Progress on these sections was sporadic throughout the fourteenth century.

17. See J. Lebeuf, Mémoires concernant l'histoire civile et ecclésiastique d'Auxerre et de son ancien diocèse, ed. Challe and Quantin, 4 vols. (Auxerre, 1848-55), IV (Preuves), No. 338, which indicates that work on the upper west façade was begun $c a$. 1500. The north tower was completed in 1543 .

18. Necrology of 1761, published in Vidier and Mirot, Obituaires, 248.

19. "5 Oct.-Ob. Stephanus Naudet, canonicus et lector hujus ecclesiae canonicus, gubernator urbis ecclesiasticus. Quiescat infra gradus portae majoris." Ibid., 265.

20. Canons are documented as having founded chapels in the cathedral in $1358,1379,1389,1410,1412,1422$ (ibid., 248-266). At this point we do not know whether there were burials in the side chapels themselves. They are not currently paved with funerary slabs, and they could not be surveyed because the sensing apparatus was not able to mount the steps to enter them.

21. A contract for the glazing of one of the new clerestory windows is dated to 1523. See Lebeuf, Mémoires, IV, No. 418.

22. Joannes de Molins, cantor, who died in 1422, donated money for the north portal of the transept (Necrology of 1761, 248). The vault keystones carry the insignia of Bishop Jean Baillet (r. 1478-1513). 